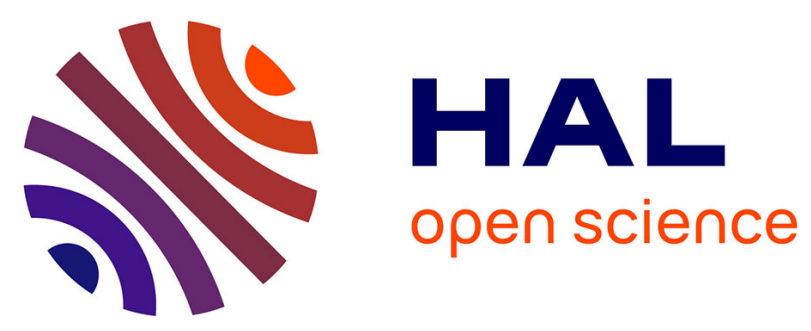

\title{
Influence of Fluorinated and Hydrogenated Nanoparticles on the Structure and Fibrillogenesis of Amyloid beta-Peptide
}

Sandra Rocha, Andreas F. Thünemann, Maria Do Carmo Pereira, Manuel Coelho, Helmuth Möhwald, Gerald Brezesinski

\section{To cite this version:}

Sandra Rocha, Andreas F. Thünemann, Maria Do Carmo Pereira, Manuel Coelho, Helmuth Möhwald, et al.. Influence of Fluorinated and Hydrogenated Nanoparticles on the Structure and Fibrillogenesis of Amyloid beta-Peptide. Biophysical Chemistry, 2008, 137 (1), pp.35. 10.1016/j.bpc.2008.06.010 . hal-00501711

\section{HAL Id: hal-00501711 \\ https://hal.science/hal-00501711}

Submitted on 12 Jul 2010

HAL is a multi-disciplinary open access archive for the deposit and dissemination of scientific research documents, whether they are published or not. The documents may come from teaching and research institutions in France or abroad, or from public or private research centers.
L'archive ouverte pluridisciplinaire HAL, est destinée au dépôt et à la diffusion de documents scientifiques de niveau recherche, publiés ou non, émanant des établissements d'enseignement et de recherche français ou étrangers, des laboratoires publics ou privés. 


\section{Accepted Manuscript}

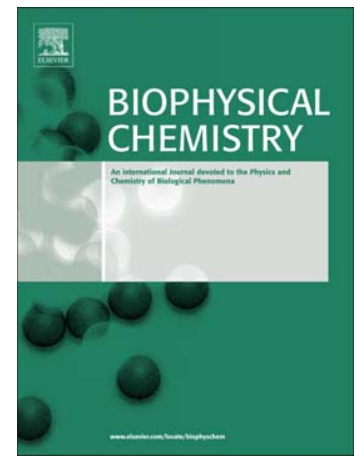

Influence of Fluorinated and Hydrogenated Nanoparticles on the Structure and Fibrillogenesis of Amyloid beta-Peptide

Sandra Rocha, Andreas F. Thünemann, Maria do Carmo Pereira, Manuel Coelho, Helmuth Möhwald, Gerald Brezesinski

PII: $\quad$ S0301-4622(08)00140-3

DOI: $\quad$ doi: $10.1016 /$ j.bpc.2008.06.010

Reference: $\quad$ BIOCHE 5130

To appear in: $\quad$ Biophysical Chemistry

Received date: 14 May 2008

Revised date: 21 June 2008

Accepted date: 23 June 2008

Please cite this article as: Sandra Rocha, Andreas F. Thünemann, Maria do Carmo Pereira, Manuel Coelho, Helmuth Möhwald, Gerald Brezesinski, Influence of Fluorinated and Hydrogenated Nanoparticles on the Structure and Fibrillogenesis of Amyloid betaPeptide, Biophysical Chemistry (2008), doi: 10.1016/j.bpc.2008.06.010

This is a PDF file of an unedited manuscript that has been accepted for publication. As a service to our customers we are providing this early version of the manuscript. The manuscript will undergo copyediting, typesetting, and review of the resulting proof before it is published in its final form. Please note that during the production process errors may be discovered which could affect the content, and all legal disclaimers that apply to the journal pertain. 


\section{Influence of Fluorinated and Hydrogenated Nanoparticles on the Structure and}

\section{Fibrillogenesis of Amyloid beta-Peptide}

Sandra Rocha, ${ }^{[\mathrm{a}]}$ Andreas F. Thünemann, ${ }^{[\mathrm{b}]}$ Maria do Carmo Pereira, ${ }^{[\mathrm{a}]}$ Manuel Coelho, ${ }^{[\mathrm{a}]}$ Helmuth Möhwald, ${ }^{[\mathrm{c}]}$ Gerald Brezesinski ${ }^{[\mathrm{c}]}$

${ }^{[a]}$ LEPAE, Dept. of Chemical Engineering, Faculty of Engineering, University of Porto, Rua Dr. Roberto Frias, 4200-465 Porto, Portugal

${ }^{[b]}$ Federal Institute for Materials Research and Testing, Richard-Willstätter-Straße 11, 12489

Berlin, Germany

${ }^{[c]}$ Max Planck Institute of Colloids and Interfaces, Wissenschaftspark, DE 14424 Golm, Potsdam, Germany

Keywords: amyloid-beta peptide, circular dichroism, conformation analysis, electron microscopy, fluorinated complexes, nanoparticles

* corresponding author

Faculty of Engineering, University of Porto

Rua Dr. Roberto Frias, 4200-465 Porto, Portugal

e-mail: sandra.rocha@fe.up.pt

phone: +351225081589

fax: +351 225081449 


\section{Abstract}

Peptide aggregation in amyloid fibrils is implicated in the pathogenesis of several diseases such as Alzheimer's disease. There is a strong correlation between amyloid fibril formation and a decrease in conformational stability of the native state. Amyloid- $\beta$ peptide $(A \beta)$, the aggregating peptide in Alzheimer's disease, is natively unfolded. The deposits found in Alzheimer's disease are composed of A $\beta$ fibrillar aggregates rich in $\beta$-sheet structure. The influence of fluorinated complexes on the secondary structure and fibrillogenesis of $A \beta$ peptide was studied by Circular Dichroism (CD) spectroscopy and Transmission Electron Microscopy (TEM). CD spectra show that complexes of polyampholyte and fluorinated dodecanoic acid induce $\alpha$-helix structure in $A \beta$, but their hydrogenated analogous lead to $\beta$-sheet formation and aggregation. The fluorinated nanoparticles with highly negative zeta potential and hydrophobic fluorinated core have the fundamental characteristics to prevent $\mathrm{A} \beta$ fibrillogenesis. 


\section{Introduction}

Soluble peptides and proteins convert, under certain conditions, into highly organized fibrillar aggregates described as amyloid fibrils and intracellular inclusions [1]. The fibrillar aggregates have a common structure of polypeptide chains organized in $\beta$-sheets. Such transition is implicated in the pathogenesis of several diseases including neurodegenerative Alzheimer’s disease (AD). The extracellular deposits that characterized AD are composed of fibrils of a small peptide with 39-43 amino acids, the amyloid- $\beta$ (A $\beta$ ) peptide [2]. $A \beta$ is continuously secreted by normal cells in culture and is detected as a soluble peptide in the plasma and cerebrospinal fluid of healthy individuals [3, 4]. In AD patients, $A \beta$ exists as insoluble fibrillar aggregates [5]. This process results from a progressive transition from natively unfolded peptide to $\beta$-sheet structure. Aggregation of $A \beta$ is preceded by the formation of series of nonfibrillar species, the protofibrils, which are by their turn preceded by other oligomeric species [1]. Prefibrillar aggregates are toxic to cells [6, 7]. The size and structure of the aggregated species appear to be associated with toxicity [8]. Oligomers are composed of 2 to 6 molecules and circular dichroism measurements show that they are relatively disorganized $[9,10]$. The lack of regular secondary structure in the small oligomers suggested that the binding of monomeric $A \beta$ to nascent fibrils requires large conformational changes and correspondingly high activation energies [11]. If peptide conformational change and aggregation represent an early event in the pathogenesis of $\mathrm{AD}$ [12], a plausible therapeutic approach would be to design molecules that control and stabilize $\mathrm{A} \beta$ secondary structure. Conditions such as long incubation times, high concentration and temperature promote $\beta$-sheet formation [13-15]. A $\beta$ forms $\beta$-sheet structure on hydrophobic graphite surfaces [16] and at air-water interface [17]. In contrast, the peptide adopts $\alpha$-helix structure in solution of negatively charged micelles and teflon particles [18-21]. Fluorinated solvents (trifluoroethanol, hexafluoroisopropanol) are described to stabilize the structure of $A \beta$ monomers at low concentrations 
(10\%), but ethanol and 2-propanol have exhibited reasonable stabilizing effects only at very high concentrations (75\%) [22].

This work focuses on the influence of hydrophilic surfaces, silica particles and hydrogenated and fluorinated nanoparticles on amyloid- $\beta$ peptide (1-40) $\left(\mathrm{A} \beta_{40}\right.$, Figure 1$)$ to better understand the conditions that stabilize the peptide helical structure. $A \beta_{40}$ solution was incubated for 6 days in sealed quartz cuvettes that were previously cleaned by the RCA procedure. The structure of the peptide in contact with hydrophilic quartz cuvettes was characterized by Circular Dichroism (CD) spectroscopy and compared with a solution stored in microcentrifuge or glass test tubes. In addition, the conformation of $A \beta_{40}$ was studied in the presence of silica particles and polyampholyte-dressed micelles [23]. The silica particles used have a diameter of $86 \mathrm{~nm}$ and a zeta potential of $-40 \mathrm{mV}$. Polyampholytes with alternating cationic (N,N'-diallyl-N,N'-dimethylammonium chloride) and anionic charged monomers (maleamic acid or N-phenylmaleamic acid) were complexed with perfluorododecanoic or hydrogenated dodecanoic acid, resulting in nanoparticles with hydrodynamic diameters of 3 to 5 nm (Figure 2) [23]. The nanoparticles were incubated with $A \beta$ and their effect on the peptide was studied by CD spectroscopy and Transmission Eelectron Microscopy (TEM). Previous work has demonstrated that the fluorinated complexes induce $\alpha$-helix structure in B18 peptide, a sequence with tendency to form amyloid fibrils [24].

\section{Material and Methods}

\section{Chemicals}

Amyloid- $\beta$ peptide (1-40) (A $\left.\beta_{40}\right)$ was purchased from Bachem (Weil am Rhein, Germany). Potassium dihydrogen phosphate, di-potassium hydrogen phosphate, sodium chloride, sodium azide, uranyl acetate, hexafluoroisopropanol, dimethyl sulfoxide and Ham’s F-12 medium were purchased from Fluka (Seelze, Germany). Silica particles were prepared according to the method reported by Stöber et al [25].

\section{Preparation of complexes}


The complexes were prepared as previously described.[23] Briefly a solution of $0.1 \mathrm{~g}$ of polyampholyte, Poly(N,N'-diallyl-N,N'dimethylammoniumalt-maleamic Carboxylate) $\left(\mathrm{P}_{1}\right)$ or Poly(N,N'-diallyl-N,N'dimethylammonium-alt- $N$-phenylmaleamic Carboxylate) $\left(\mathrm{P}_{2}\right)$, in $100 \mathrm{~mL}$ of water was adjusted to $\mathrm{pH} 8$ using sodium hydroxide solution $\left(0.1 \mathrm{~mol} \mathrm{~L}^{-1}\right)$ and heated to $90^{\circ} \mathrm{C}$. A solution $\left(100 \mathrm{~mL}, 90^{\circ} \mathrm{C}\right)$ of 1.0 equiv of the dodecanoic acid and perfluorododecanoic acid, respectively, was added in droplets to the polyampholyte solution, which was then adjusted to $\mathrm{pH}$ 8. The mixture was stirred for $60 \mathrm{~min}$ at $90{ }^{\circ} \mathrm{C}$ and then cooled to room temperature.

\section{Peptide solution}

$\mathrm{A} \beta_{40}$ was dissolved at a concentration of $1 \mathrm{mg} / \mathrm{mL}$ in $100 \%$ hexafluorisopropanol (HFIP). The solution was incubated at room temperature for several hours. The peptide/HFIP solution was dried down under a gentle stream of nitrogen gas and the peptide was resuspended in $10 \mathrm{mM}$ potassium phosphate buffer (pH 7.4) with or without $\mathrm{NaCl}(0.5 \mathrm{M} \mathrm{NaCl}$; final concentration $0.1 \mathrm{M}$ ) for CD spectroscopy or $100 \%$ dimethyl sulfoxide for TEM. Sodium azide $(0.05 \mathrm{mM})$ was added to prevent microbial growth.

\section{Cuvette modification}

Quartz cuvettes (Hellma GmbH, Germany) were carefully cleaned to obtain hydrophilic surfaces. The cuvettes were treated by the RCA method: immersion in solution of $\mathrm{H}_{2} \mathrm{O}_{2}(30 \%)+\mathrm{H}_{2} \mathrm{O}+\mathrm{NH}_{3}(30 \%)$, ratio 1:5:1 by volume, heated to $80^{\circ} \mathrm{C}$ for $10 \mathrm{~min}$, followed by rinsing with Milli-Q-water. After RCA the surface is well saturated with silanol groups, conferring very high hydrophilicity. Above $\mathrm{pH} 2$, the oxide surface is negatively charged.

\section{Circular dichroism (CD) spectroscopy}

Far UV CD spectra of $A \beta_{40}$ solution were recorded in a Jasco J-715 Spectropolarimeter (Jasco Co., Tokyo, Japan), using a cuvette with 0.5 or $1 \mathrm{~mm}$ path length at $0.2 \mathrm{~nm}$ intervals between 190 and $260 \mathrm{~nm}$. The spectra were taken as the average of 10 scans recorded at a speed of $20 \mathrm{~nm} / \mathrm{min}$. The peptide conformation was analyzed during incubation (6 days) in quartz cuvettes and in the presence of 
particles at room temperature and at $37^{\circ} \mathrm{C}$. Spectra were corrected by subtracting the buffer or particle solution baseline.

The content of secondary structure motifs was calculated using the CONTIN/LL, a self-consistent method with an incorporated variable selection procedure included in the CDPro software.[26] Before secondary structure analysis, the CD spectra were smoothed using the noise reduction routines provided with the J-715 spectropolarimeter. In general, CONTIN/LL program with the reference set including unordered structures produced the most reliable results.[27] Normalized root mean standard deviation (NRMSD) was used to determine the quality of the fit of the calculated structure to the data and was less than 0.1. Although the program used to calculate the secondary structure elements is meant for proteins, the reference set with unordered structures gave consistent results. These results give an idea on changes in the secondary structure and on the predominant structure motif of A $\beta$. Other programs such as CDNN/PEPFIT were not suitable for deconvolute the spectra resulting in errors higher than $10 \%$, even with a base spectra of polypeptides $[28,29]$. The problem is probably related to the fact that the base spectra are from homopolymers or binary and trinary copolymers. The intensity and position of the CD bands for a given secondary structure can vary significantly with the side chain. Spectra constructed from an average of the spectra existent in the literature for a number of different model peptides to ameliorate this problem, as performed for CDNN/PEPFIT program,[28] was not sufficient to give consistent results for $A \beta$ spectra.

\section{Dynamic Light Scattering (DLS)}

The hydrodynamic radius of the particles was measured by DLS on a Malvern Zetasizer Nano ZS. The samples were filtered with $0.2 \mu \mathrm{m}$ syringe filter before measurement. All data were averaged from 5 measurements.

\section{Transmission electron microscopy (TEM)}

$\mathrm{A} \beta_{40} / \mathrm{DMSO}$ was added to the control (Ham’s F-12) or complexes and Ham’s F-12 medium (diluted; final ionic strength $0.04 \mathrm{M}$ ) to a peptide final concentration of $100 \mu \mathrm{M}(\mathrm{pH} 7.4)$. The samples were 
incubated for 6 days at $37^{\circ} \mathrm{C}$. Aliquots of $5 \mu$ l of each sample immediately after preparation and at 6 days incubation time were adsorbed for 2 min to formvar-coated Ni grids. Grids were washed with ultrapure water 3 times and negatively stained with $1 \%$ filtered uranyl acetate solution for visualization by TEM (Zeiss microscope operated at $60 \mathrm{kV}$ ).

\section{Results}

$\mathrm{A} \beta_{40}(40 \mu \mathrm{M})$ was incubated in sealed quartz cuvettes of $1 \mathrm{~mm}$ path length previously cleaned by RCA method, for 6 days, at room temperature $\left(20 \pm 1^{\circ} \mathrm{C}\right)$ and $\mathrm{pH}$ 7.4. $\mathrm{CD}$ measurements showed that the peptide is mainly in unordered conformation (minimum at $198 \mathrm{~nm}$ ) when in contact with hydrophilic quartz surfaces and no structural changes are observed during the incubation period (Figure 3 a). As opposed to that, the $C D$ spectrum of $A \beta_{40}$ solution incubated 6 days in microcentrifuge tubes or glass tubes has a broad band at $214 \mathrm{~nm}$ and a positive band at $192 \mathrm{~nm}$ (Figure $3 \mathrm{~b}$ ). Secondary structure estimation resulted in a content of $3 \% \alpha$-helix, 25\% $\beta$-sheet and 59\% unordered at initial time and $14 \%$ $\alpha$-helix, 34\% $\beta$-sheet and 31\% unordered (Table 1) after 6 days incubation time. Similar behavior is observed at $37^{\circ} \mathrm{C}$, but the conformational transition in test tubes occurs faster when compared to that at room temperature (data not shown).

The measured CD spectrum of $A \beta_{40}(50 \mu \mathrm{M})$ in solution of negatively charged silica particles is shown in Figure 4. It can be seen that the peptide displays the typical spectrum of unordered protein in the presence of silica particles, similar to that observed in the absence of particles.

The conformation of $\mathrm{A} \beta_{40}(50 \mu \mathrm{M})$ was additionally characterized in solutions of $0,2,4$ and $8 \mathrm{~g} \mathrm{~L}^{-1}$ of complexes, which are polyampholytes of a cationic and anionic monomers (maleamic acid, $\mathrm{P}_{1}$ or phenylmaleamic acid, $\mathrm{P}_{2}$ ) complexed with perfluorododecanoic $(\mathrm{F})$ or hydrogenated dodecanoic acid (H) (Figure 2). The particles have a hydrophobic core (formed by the surfactant chains) and a hydrophilic shell (polyampholyte). The hydrodynamic diameters are in the range of 3 to $5 \mathrm{~nm}$ (Figure 5 a). The zeta potentials are highly negative for fluorinated complexes, with values of $-(47 \pm 5) \mathrm{mV}$ when 
$R$ is the hydrogen $\left(\mathrm{P}_{1} \mathrm{~F}\right)$ and $-(48 \pm 5) \mathrm{mV}$ when $R$ is the phenyl group $\left(\mathrm{P}_{2} \mathrm{~F}\right)$ [23]. The hydrogenated complexes display zeta potentials of $+(25 \pm 10) \mathrm{mV}\left(\mathrm{P}_{1} \mathrm{H}\right)$ and $-(20 \pm 4) \mathrm{mV}\left(\mathrm{P}_{2} \mathrm{H}\right)$ (Figure $5 \mathrm{~b}$ ). The concentrations of complexes were chosen to be above their critical aggregation concentration $\left(\mathrm{P}_{1}, 1 \mathrm{~g} \mathrm{~L}^{-}\right.$ $\left.{ }^{1} ; \mathrm{P}_{2}, 10^{-2} \mathrm{~g} \mathrm{~L}^{-1}\right)$. The measured CD spectra of $\mathrm{A} \beta_{40}$ solution with and without complexes are shown in Figure 6 and 7. In the absence of particles, $A \beta_{40}$ displays the typical spectrum (curve 1 ) of a unordered protein. The secondary structure estimation resulted in a content of $3 \% \alpha$-helix, $27 \% \beta$-sheet, $14 \% \beta$ turn and 56\% unordered. The titration with increasing amount of fluorinated complexes $\mathrm{P}_{1} \mathrm{~F}$ induces a change from unordered to $\alpha$-helix structure as shown in Figure 6 a (curves 2 to 4 ). The presence of an isosbestic point at $203 \mathrm{~nm}$ is indicative for a two state transition from unordered to $\alpha$-helix. The content of $\alpha$-helix was $8 \%, 16 \%$ and $31 \%$ after the addition of 2,4 and $8 \mathrm{~g} \mathrm{~L}^{-1} \mathrm{P}_{1} \mathrm{~F}$ complexes, respectively (Figure 8 a). The unordered structure decreased to $27 \%$, whereas the content of $\beta$-structures was approximately constant. The hydrogenated complexes $\mathrm{P}_{1} \mathrm{H}$, in contrast to their fluorinated analogous, did not induce $\alpha$-helix rich structure on $A \beta_{40}$ (Figure 6 b). The titration of $A \beta_{40}$ with $P_{1} H$ resulted in CD spectra of typical $\beta$-sheet protein. The fraction of $\beta$-sheet increased from $27 \%$ to $37 \%$ and the unordered content decreased from 56\% to $37 \%$ (Figure 8 b). After addition of fluorinated particles $\mathrm{P}_{2} \mathrm{~F}$ the spectra were reminiscent of $\alpha$-helix structure, particularly at high complex concentration (8 g L ${ }^{-1}$ ), as observed in Figure 7 (a). In this case the increase in $\alpha$-helix content was, however, smaller (from 3\% to 21\%) than the increase observed after addition of $8 \mathrm{~g} \mathrm{~L}^{-1}$ of complex $\mathrm{P}_{1} \mathrm{~F}$ (from $3 \%$ to 31\%), as shown in Table 2. The unordered fraction decreased to $36 \%$. The titration of $A \beta_{40}$ with hydrogenated complexes $\mathrm{P}_{2} \mathrm{H}$ resulted in a decrease of the circular dichroism signal with increasing concentration of the complexes (Figure $7 \mathrm{~b}$ ), suggesting the occurrence of aggregation. The presence of peptide aggregates is known to reduce the circular dichroism signal intensity due to light scattering and a shadowing effect [30]. 
The secondary structure of $A \beta_{40}$ in contact with $\mathrm{P}_{1}$ nanoparticles $\left(8 \mathrm{~g} \mathrm{~L}^{-1}\right)$ was analysed in the presence of salt $(0.1 \mathrm{M} \mathrm{NaCl})$ at $37^{\circ} \mathrm{C}$. Figure 9 shows that $\mathrm{P}_{1} \mathrm{~F}$ induces a small change in the $\mathrm{CD}$ spectrum of $A \beta_{40}$ when salt is present. A higher nanoparticle concentration is needed to have the helical effect observed in the absence of salt. $\mathrm{P}_{1} \mathrm{H}$ nanoparticles induced aggregation and sedimentation and thus CD measurement could not be performed.

Since $P_{1} F$ shows higher $\alpha$-helix inducing effect, $A \beta_{40}$ was incubated with $P_{1}$ complex $\left(8 \mathrm{~g} \mathrm{~L}^{-1}\right)$ for 6 days at $37^{\circ} \mathrm{C}$ to evaluate its ability to inhibit $\mathrm{A} \beta$ aggregation. The incubation was performed at low ionic strength $(0.04 \mathrm{M})$ to accelerate the fibril formation. Aliquots were taken immediately after sample preparation and at 6 days incubation time to be observed by TEM. After sample preparation, TEM shows already the presence of spherical $\mathrm{A} \beta$ aggregates and short fibrils, which may correspond to protofibrils (Figure 10, planes a and c).[31] $\mathrm{A} \beta_{40}$ incubated alone for 6 days at $37^{\circ} \mathrm{C}$ formed amyloidlike fibrils (Figure 10, plane b). However when the peptide was co-incubated from the beginning with fluorinated complexes, long and unbranched fibrils are not any longer visible (Figure 10, plane d). It is not possible to determine unambiguously whether the spherical structures observed are A $\beta$ aggregates or complex aggregates. However, these structures are similar to the ones observed for the complexes incubated alone (Figure 10, panel e and f). In addition spherical A $\beta$ aggregates are more electron lucent than the complexes, indicating that the spherical structure are aggregates of the complexes. The coincubation of $A \beta_{40}$ with $\mathrm{P}_{1} \mathrm{H}$ resulted in amyloid fibril formation (Figure 11), demonstrating that these particles are not able of inhibiting amyloid fibril formation.

\section{Discussion}

$\mathrm{A} \beta$ is detected as a circulating peptide in the plasma and cerebrospinal fluid of healthy individuals [3, 4]. Under physiological conditions, the peptide appears to be unfolded at the beginning of the aggregation. NMR studies have shown that monomers exist predominately as random extended chains, without $\alpha$-helical or $\beta$-sheet structures [32]. However, amyloid deposits isolated from AD brain tissue 
are composed predominantly of $\mathrm{A} \beta$ in a $\beta$-pleated sheet conformation [33]. Although a causal relationship between peptide deposition and the development of $\mathrm{AD}$ is not conclusively proved, it was observed that the fibrillar and the oligomeric forms of the peptide, but not the monomeric form, cause changes in cultured neurons [34, 35].

This work demonstrates that negatively charged surfaces inhibit the conformational transition of $A \beta_{40}$ from unfolded to $\beta$-sheet that normally occurs if the peptide is incubated at room temperature or at 37 ${ }^{\circ} \mathrm{C}$ in test tubes. This might be explained by the fact that negatively charged groups prevent the interaction between peptide molecules since they can interact directly with polar side chains in unfolded peptide, inhibiting conformational transitions. However $A \beta_{40}$ does not adsorb irreversibly on negatively charged surfaces, as demonstrated by previous results obtained with neutron reflectivity measurements [21]. This indicates a dynamic interaction where peptide molecules are going to the surface and to the bulk phase. After incubation in test tubes, $A \beta_{40}$ undergoes conformational changes. In this case, the peptide is more in contact with air than when incubated in hydrophilic quartz cuvettes (that were hermetically closed) and conformational transitions can not be prevented. The peptide was previously found to adsorb at air-water interface, which acts as a hydrophobic-hydrophilic surface and merely $\beta$ sheet structure was detected [17].

Negatively charged silica particles do not induce structural changes in the peptide. However when fluorinated complexes are added to $A \beta_{40}$ solution an $\alpha$-helix structure is observed, whereas hydrogenated analogues lead to $\beta$-sheet formation and aggregation. Previous studies have shown that hydrophobic teflon particles with a size of $200 \mathrm{~nm}$ and a zeta potential of $-47 \mathrm{mV}$ are able to induce $\alpha$ helix structure in $A \beta_{40}$ [20]. Interactions between hydrophobic residues and fluorinated chains must stabilize the peptide intramolecular hydrogen bonds, to the detriment of any intermolecular hydrogen bonding with water. Organofluorine compounds are effective inhibitors of A $\beta$ self-assembly [37]. The inhibitor activity of these compounds was attributed to the acidic character of a hydroxyl group, that 
increases by introducing the strongly electron withdrawing $\mathrm{CF}_{3}$ group. Perfluorododecanoic acid is a stronger acid than dodecanoic, suggesting that the acidic character plays as well a key role in $\alpha$-helix formation. This is support by the observation of a smaller structural change when measurements are performed in the presence of salt $(\mathrm{NaCl} 0.1 \mathrm{M})$. Montserret et. al. have shown that while the folding of peptides in sodium dodecy sulphate (SDS) micelles is mostly driven by hydrophobic effects, electrostatic interactions play a significant role in the formation and the stabilization of $\alpha$-helix structure [38]. Usually, this structure is induced upon dehydrating apolar sites of the peptide and the micelle, directly related to hydrophobic interactions, in line with current thoughts about the formation of local secondary structure [39, 40]. However the role of both charged and hydrophobic amino acid side chains is essential in the sequential cooperative process of the SDS-induced mechanism of $\alpha$-helix formation. In the absence of electrostatic interactions, the binding of hydrophobic C12 tails is not able to form a stable peptide-detergent complex allowing the formation of a hydrophobic environment required for helix stabilization [38]. The fact that fluorinated complexes show high negative surface charges seems to be determinant to the folding. However, it is not sufficient since silica particles that have a zeta potential in the order of that of fluorinated ones can not induce $\alpha$-helices.

Hydrogenated complexes are not able of inducing an $\alpha$-helix structure in $A \beta_{40}$, but rather $\beta$-sheets and aggregation. The reason might be that dodecanoic acid is less hydrophobic than perfluorododecanoic. Taking into consideration that SDS micelles, that are formed by a core of hydrogenated C12 chains, induce $\alpha$-helix structure in $A \beta_{40}$, $[18,19]$ the charge contribution has to be important. It has been demonstrated that SDS adsorbed on the surface of activated carbons and carbon blacks gives a zeta potential in the order of $-50 \mathrm{mV}$ [41]. Thus the lower zeta potentials in absolute numbers of hydrogenated complexes contribute to the fact that these particles are not able of preventing the interaction between peptide molecules, resulting in aggregation. The lower efficiency of fluorinated complex with the phenyl group on the polyampholyte $\left(\mathrm{P}_{2} \mathrm{~F}\right)$ compared with the complex with hydrogen 
$\left(\mathrm{P}_{1} \mathrm{~F}\right)$ can be understood as a steric effect. The phenyl group sterically hinders the hydrophobic residues on the peptide from interacting with fluorine groups.

Fluorinated complexes, but not their hydrogenated analogues, inhibited the amyloid fibril formation by $A \beta_{40}$. This result supports the concept that the formation of a $\beta$-sheet secondary structure is related to fibrillogenesis. It is likely that fluorinated complexes inhibit amyloid formation by binding to monomeric $A \beta_{40}$. The central hydrophobic cluster of $A \beta$ (residues 17-21 LVFFA) has been particularly implicated in amyloid fibril formation [43]. $\mathrm{CF}_{3}$ groups can interact with hydrophobic peptide residues, preventing hydrophobic interactions between peptide molecules. In addition X-ray and electron diffraction have shown that $\beta$-sheets are stabilized by bonding between adjacent phenylalanine rings and salt-bridges between charge pairs (glutamic acid-lysine) [42]. The nanostructures presented in this study can replace the acidic residues of the peptide and inhibit the self-assembly. Vieira e al. suggested that the loss of ordered water coating around the peptide, indirectly induced by structuring of water around the $\mathrm{CF}_{3}$ groups of fluorinated alcohols and by the presence of $\mathrm{CF}_{3}$ near the peptide, causes the $\mathrm{NH}$ and $\mathrm{C}=\mathrm{O}$ groups of the backbone to interact on short distances with each other, favoring the $\alpha$-helix [22]. Short-range interactions between nearby amino acid residues stabilize the $\alpha$-helical structure in contrast to long-range interactions stabilizing the $\beta$-sheet structure.

\section{Conclusions}

Negatively charged surfaces and silica particles are not capable of inducing $\alpha$-helix structure in $A \beta_{40}$, although they inhibit $\beta$-sheet structure formation. Fluorinated complexes are able to induce $\alpha$-helix structure and prevent fibril formation. Adding hydrogenated complexes to the peptide solution resulted in $\beta$-sheets and aggregation. Supporting the fact that $\beta$-sheet secondary structures are usually stabilized by protein aggregation and directly related to fibrillogenesis, hydrogenated complexes lead to amyloid fibril formation. According to the results presented here, it seems reasonable to assume that both high 
charged density and hydrophobic groups are necessary to stabilize $\alpha$-helix structure in $\mathrm{A} \beta_{40}$ peptide and consequently to inhibit fibril formation. The fluorinated complexes with highly negative zeta potential and hydrophobic fluorinated core have the fundamental characteristics to prevent $A \beta_{40}$ fibrillogenesis.

\section{Acknowledgment}

S. Rocha thanks the FCT for a Fellowship (BPD/25641/2005). These investigations were supported by FCT research project PTDC/BIO/69359/2006, Max Planck Society, Fraunhofer Society and Federal Institute of Material Research and Testing. Isabel Cardoso (IBMC) is gratefully acknowledged for scientific discussions. We thank Heidi Zastrow (MPI) and Rui Fernandes for assistance in DLS and TEM measurements, respectively. 


\section{Figure Legend}

Figure 1. Amino acid sequence of $A \beta_{40}$.

Figure 2. Complexes of polyampholytes and the sodium salt of dodecanoic acid $(X=H)$ and perfluorododecanoic acid $(\mathrm{X}=\mathrm{F}) \cdot[23]$

Figure 3. CD spectra of $A \beta_{40}(40 \mu \mathrm{M})$ stored in negatively charged quartz cuvettes (a) and in test tubes (b) at different times: 10 minutes (curve 1), 6 days (curve 2). The curves of (a) overlap.

Figure 4. CD data of $A \beta_{40}(50 \mu \mathrm{M})$ in the absence (1) and presence (2) of silica particles.

Figure 5. Particle size distribution of the hydrogenated complex $\mathrm{P}_{2} \mathrm{H}$ as determined by DLS measurements (a) and zeta potentials of the polyampholyte complexes with dodecanoic acid (•) and perfluorododecanoic acid (ם).

Figure 6. CD data of $A \beta_{40}(50 \mu \mathrm{M})$ in the presence of different concentrations of fluorinated (a) and hydrogenated (b) $\mathrm{P}_{1}$ complexes: $0 \mathrm{~g} \mathrm{~L}^{-1}$ (curve 1), $2 \mathrm{~g} \mathrm{~L}^{-1}$ (curve 2), $4 \mathrm{~g} \mathrm{~L}^{-1}$ (curve 3) and $8 \mathrm{~g} \mathrm{~L}^{-1}$ (curve 4).

Figure 7. CD data of $A \beta_{40}(50 \mu \mathrm{M})$ in the presence of different concentrations of fluorinated (a) and hydrogenated (b) $\mathrm{P}_{2}$ complexes: $0 \mathrm{~g} \mathrm{~L}^{-1}$ (curve 1), $2 \mathrm{~g} \mathrm{~L}^{-1}$ (curve 2), $4 \mathrm{~g} \mathrm{~L}^{-1}$ (curve 3) and $8 \mathrm{~g} \mathrm{~L}^{-1}$ (curve 4).

Figure 8. Percentage of secondary structure motifs of $A \beta_{40}$ in the presence of different concentrations

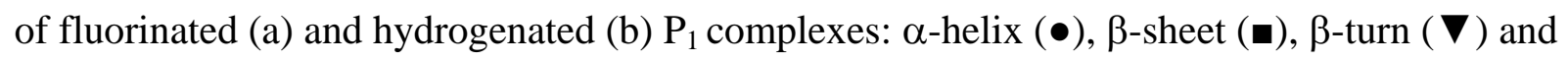
unordered $(\diamond)$.

Figure 9. CD spectra of $A \beta_{40}(50 \mu \mathrm{M})$ in phosphate buffer containing $0.1 \mathrm{M} \mathrm{NaCl}$ in the absence (curve 1) and presence of $8 \mathrm{~g} \mathrm{~L}^{-1}$ of fluorinated $\mathrm{P}_{1}$ complex.

Figure 10. Electron microscopy analysis of the effect of fluorinated complexes on fibril formation. A $\beta_{40}$ $(100 \mu \mathrm{M})$ was incubated with or without fluorinated complexes $\left(8 \mathrm{~g} \mathrm{~L}^{-1}\right)$ at $37^{\circ} \mathrm{C}$. a. $\mathrm{A} \beta_{40}$ alone immediately after preparation. b. $A \beta_{40}$ alone incubated for 6 days. c. $A \beta_{40}$ with fluorinated complexes 
immediately after preparation.d. $A \beta_{40}$ with fluorinated complexes incubated for 6 days. e. Fluorinated complexes alone immediately after preparation. f. Fluorinated complexes alone incubated for 6 days. The scale bar in panel $\mathbf{a}$ is $200 \mathrm{~nm}$ and the same magnification was used in all panels.

Figure 11. Electron microscopy analysis of $A \beta_{40}(100 \mu \mathrm{M})$ incubated with hydrogenated complexes (8 $\mathrm{g} \mathrm{L}^{-1}$ ) at $37^{\circ} \mathrm{C}$. The scale bar is $200 \mathrm{~nm}$. 


\section{Figures}

\section{Figure 1}

\section{DAEFRHDSGYEVHHQKLVFFAEDVGSNKGAIIGLMVGGVV}

\section{Figure 2}

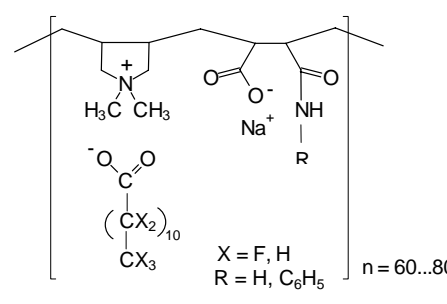

$\mathbf{R}=\mathbf{H}: P_{1} F(X=F) ; P_{1} H(X=H)$

$\mathbf{R}=\mathbf{C}_{6} \mathbf{H}_{5}: \mathrm{P}_{2} \mathrm{~F}(X=\mathrm{F}) ; \mathrm{P}_{2} \mathrm{H}(X=\mathrm{H})$

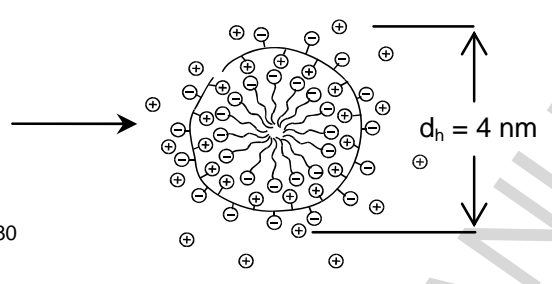

Figure 3
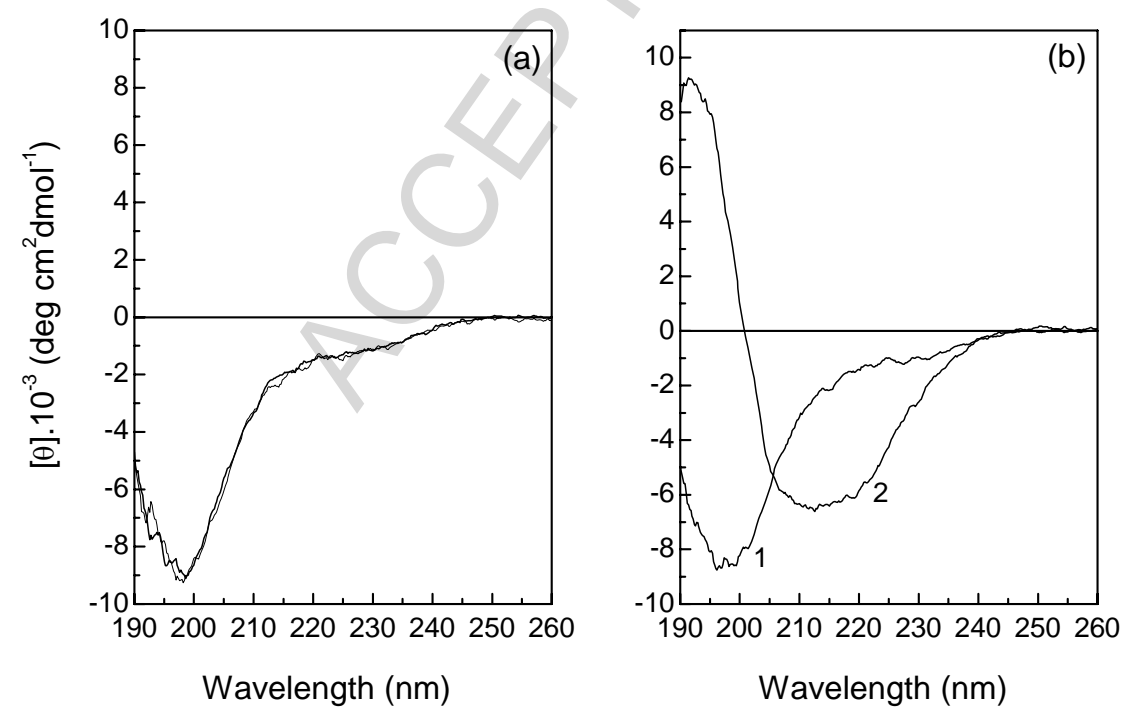


\section{Figure 4}

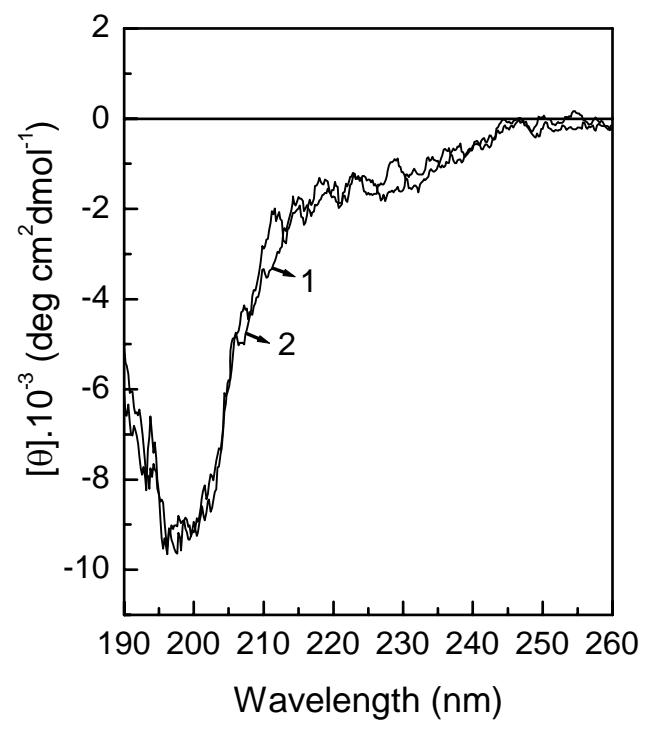

\section{Figure 5}
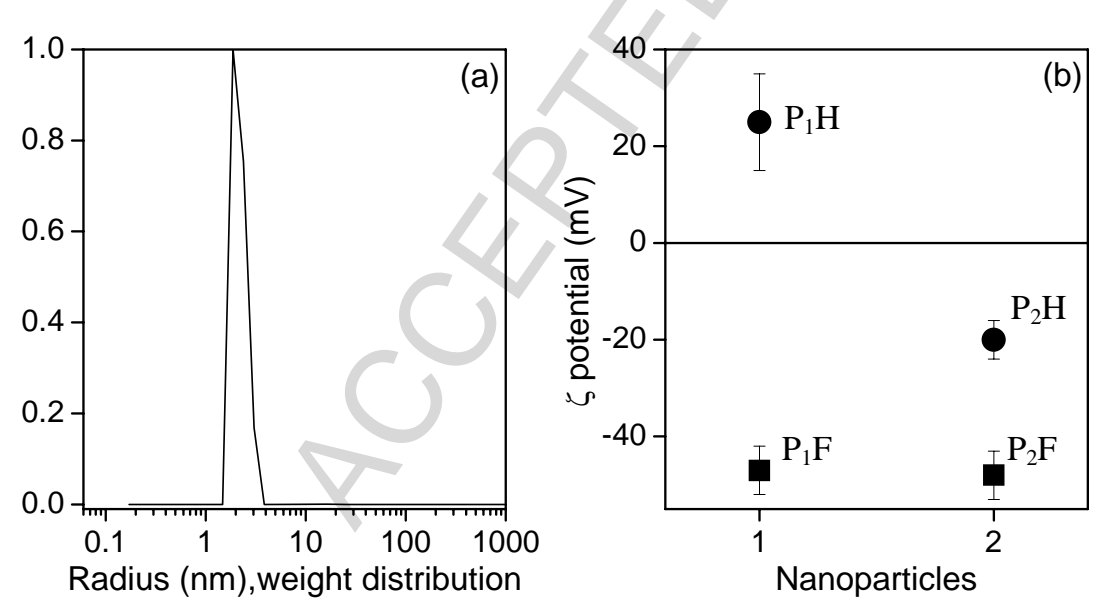


\section{Figure 6}
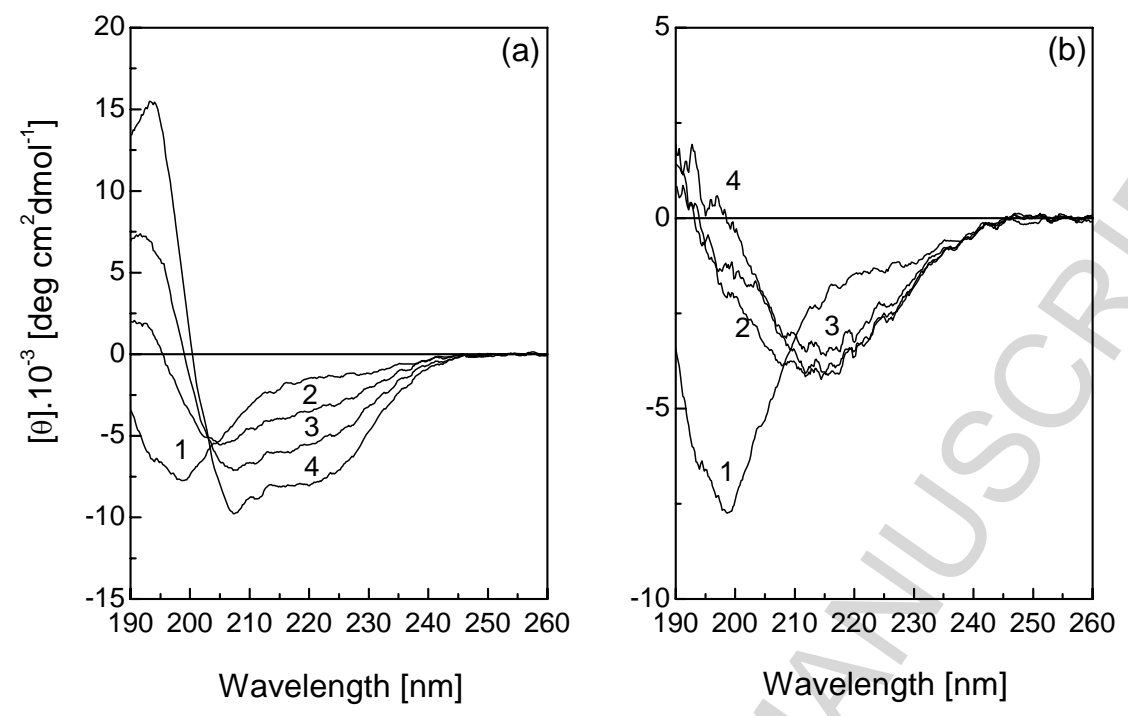

Figure 7
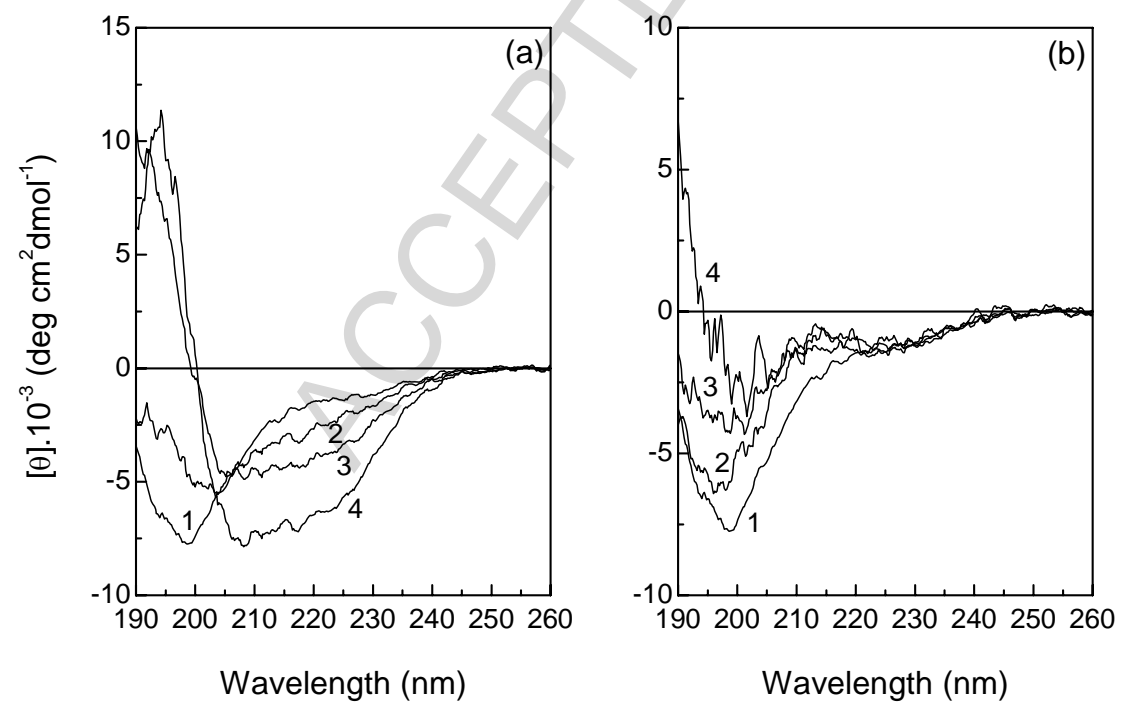


\section{Figure 8}
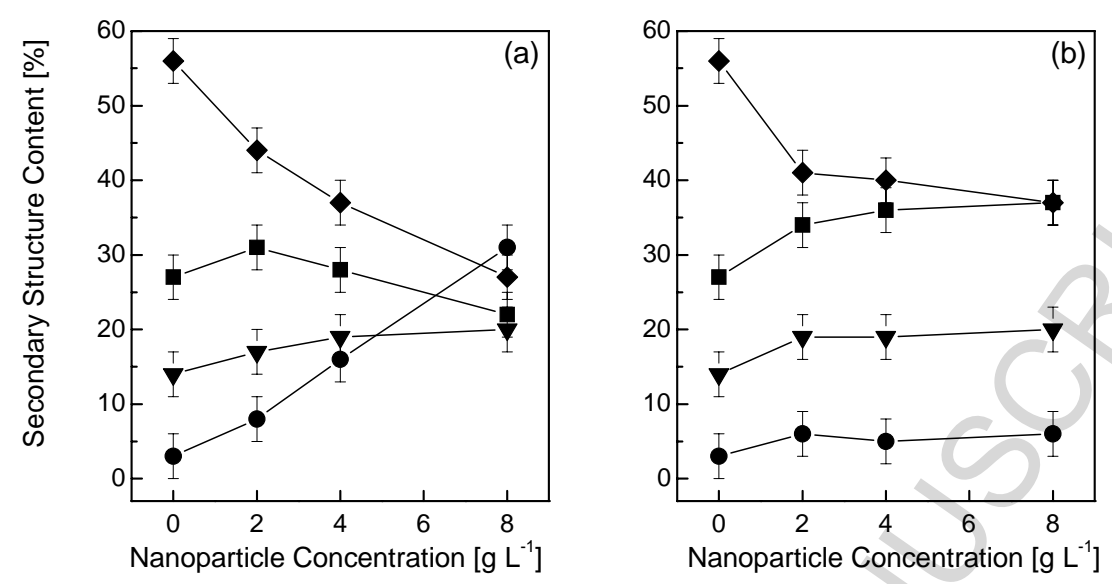

Figure 9

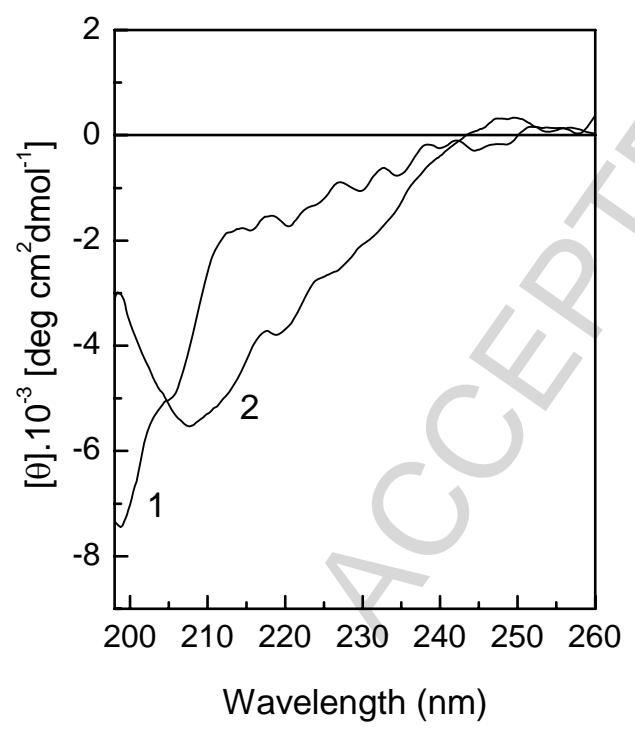


Figure 10
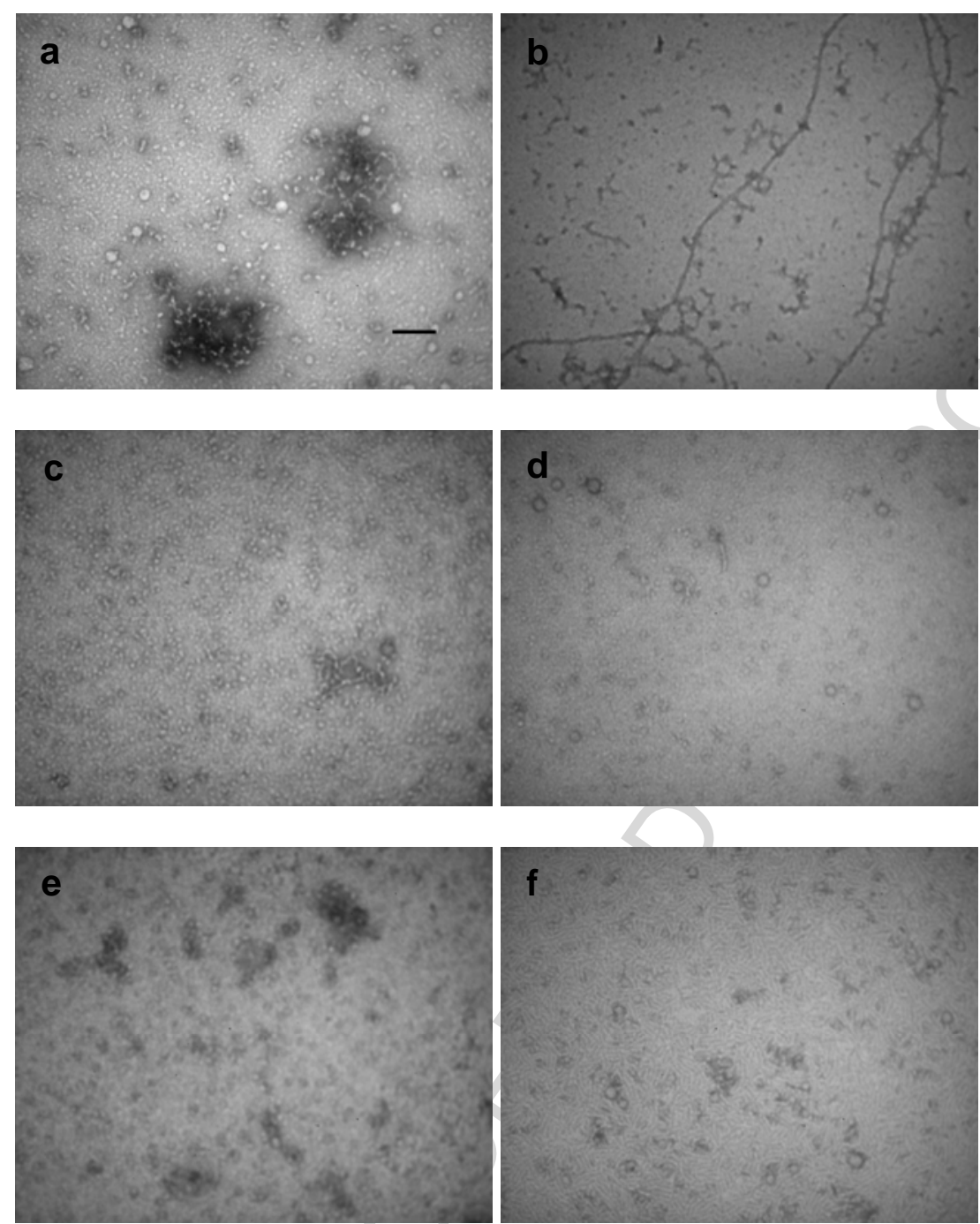

Figure 11

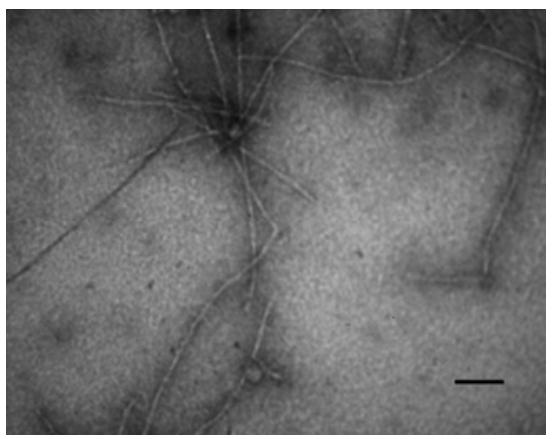




\section{Table 1}

Percentage of secondary structure motifs $( \pm 3 \%)$ of $A \beta_{40}$ incubated in microcentrifuge or glass tubes.

\begin{tabular}{lllll}
\hline Time (days) & Helix & Strand & Turn & Unordered \\
\hline 0 & 3 & 25 & 13 & 59 \\
6 & 14 & 34 & 21 & 31 \\
\hline
\end{tabular}

\section{Table 2}

Percentage of secondary structure motifs ( $\pm 3 \%$ ) of $A \beta_{40}$ in the presence of fluorinated complexes $\mathrm{P}_{2} \mathrm{~F}$ at different concentrations.

\begin{tabular}{lllll}
\hline Conc. $\left(\mathrm{g} \mathrm{L}^{-1}\right)$ & Helix & Strand & Turn & Unordered \\
\hline 0 & 3 & 27 & 14 & 56 \\
2 & 4 & 29 & 15 & 52 \\
4 & 8 & 33 & 21 & 38 \\
8 & 21 & 24 & 19 & 36 \\
\hline
\end{tabular}




\section{References}

[1]F. Chiti, and C. M. Dobson, Protein Misfolding, Functional Amyloid, and Human Disease, Annu. Rev. Biochem. 75 (2006), 333-366.

[2]C. L. Masters, G. Simms, N. A. Weinman, G. Multhaup, B. L. Mcdonald, and K. Beyreuther, Amyloid Plaque Core Protein in Alzheimer-Disease and Down Syndrome, Proc. Natl. Acad. Sci. U. S. A. 82 (1985), 4245-4249.

[3]C. Haass, M. G. Schlossmacher, A. Y. Hung, C. Vigopelfrey, A. Mellon, B. L. Ostaszewski, I. Lieberburg, E. H. Koo, D. Schenk, D. B. Teplow, and D. J. Selkoe, Amyloid Beta-Peptide Is Produced by Cultured-Cells During Normal Metabolism, Nature 359 (1992), 322-325.

[4]P. Seubert, C. Vigopelfrey, F. Esch, M. Lee, H. Dovey, D. Davis, S. Sinha, M. Schlossmacher, J. Whaley, C. Swindlehurst, R. Mccormack, R. Wolfert, D. Selkoe, I. Lieberburg, and D. Schenk, Isolation and Quantification of Soluble Alzheimers Beta-Peptide from Biological-Fluids, Nature 359 (1992), 325-327.

[5]D. J. Selkoe, Alzheimer's Disease: Genes, Proteins, and Therapy, Physiol. Rev. 81 (2001), 741-766.

[6]M. P. Lambert, A. K. Barlow, B. A. Chromy, C. Edwards, R. Freed, M. Liosatos, T. E. Morgan, I. Rozovsky, B. Trommer, K. L. Viola, P. Wals, C. Zhang, C. E. Finch, G. A. Krafft, and W. L. Klein, Diffusible, Nonfibrillar Ligands Derived from a Beta(1-42) Are Potent Central Nervous System Neurotoxins, Proc. Natl. Acad. Sci. U. S. A. 95 (1998), 6448-6453.

[7]C. Haass, and D. J. Selkoe, Soluble Protein Oligomers in Neurodegeneration: Lessons from the Alzheimer's Amyloid Beta-Peptide, Nature Reviews Molecular Cell Biology 8 (2007), 101-112.

[8]S. S. S. Wang, A. Becerra-Arteaga, and T. A. Good, Development of a Novel Diffusion-Based Method to Estimate the Size of the Aggregated a Beta Species Responsible for Neurotoxicity, Biotechnol. Bioeng. 80 (2002), 50-59.

[9]T. H. J. Huang, D. S. Yang, N. P. Plaskos, S. Go, C. M. Yip, P. E. Fraser, and A. Chakrabartty, Structural Studies of Soluble Oligomers of the Alzheimer Beta-Amyloid Peptide, J. Mol. Biol. 297 (2000), 73-87.

[10]G. Bitan, M. D. Kirkitadze, A. Lomakin, S. S. Vollers, G. B. Benedek, and D. B. Teplow, Amyloid BetaProtein (a Beta) Assembly: A Beta 40 and a Beta 42 Oligomerize through Distinct Pathways, Proc. Natl. Acad. Sci. U. S. A. 100 (2003), 330-335.

[11]Y. Kusumoto, A. Lomakin, D. B. Teplow, and G. B. Benedek, Temperature Dependence of Amyloid BetaProtein Fibrillization, Proc. Natl. Acad. Sci. U. S. A. 95 (1998), 12277-12282.

[12]D. J. Selkoe, Toward a Comprehensive Theory for Alzheimer's Disease. Hypothesis:Alzheimer's Disease Is Caused by the Cerebral Accumulation and Cytotoxicity of Amyloid B-Protein, Ann. NY Acad. Sci. 924 (2000), 17-25.

[13]C. Hilbich, B. Kisterswoike, J. Reed, C. L. Masters, and K. Beyreuther, Aggregation and Secondary Structure of Synthetic Amyloid Beta-A4 Peptides of Alzheimers-Disease, J. Mol. Biol. 218 (1991), 149-163.

[14]C. J. Barrow, A. Yasuda, P. T. M. Kenny, and M. G. Zagorski, Solution Conformations and Aggregational Properties of Synthetic Amyloid Beta-Peptides of Alzheimers-Disease - Analysis of Circular-Dichroism Spectra, J. Mol. Biol. 225 (1992), 1075-1093.

[15]H L Chu, and S Y Lin, Temperature-Induced Conformational Changes in Amyloid Bnext Term(1-40) Previous Termpeptidenext Term Investigated by Simultaneous Ft-Ir Microspectroscopy with Thermal System, Biophysical Chemistry 89 (2001), 173-180.

[16]T. Kowalewski, and D. M. Holtzman, In Situ Atomic Force Microscopy Study of Alzheimer's Beta-Amyloid Peptide on Different Substrates: New Insights into Mechanism of Beta-Sheet Formation, Proc. Natl. Acad. Sci. U. S. A. 96 (1999), 3688-3693.

[17]C. Schladitz, E. P. Vieira, H. Hermel, and H. Mohwald, Amyloid-Beta-Sheet Formation at the Air-Water Interface, Biophys. J. 77 (1999), 3305-3310.

[18]M. Coles, W. Bicknell, A. A. Watson, D. P. Fairlie, and D. J. Craik, Solution Structure of Amyloid BetaPeptide(1-40) in a Water-Micelle Environment. Is the Membrane-Spanning Domain Where We Think It Is?, Biochemistry 37 (1998), 11064-11077.

[19]H. Y. Shao, S. C. Jao, K. Ma, and M. G. Zagorski, Solution Structures of Micelle-Bound Amyloid Beta-(140) and Beta-(1-42) Peptides of Alzheimer's Disease, J. Mol. Biol. 285 (1999), 755-773.

[20]C. E. Giacomelli, and W. Norde, Conformational Changes of the Amyloid Beta-Peptide (1-40) Adsorbed on Solid Surfaces, Macromolecular Bioscience 5 (2005), 401-407. 
[21]S. Rocha, R. Krastev, A. F. Thunemann, M. C. Pereira, H. Mohwald, and G. Brezesinski, Adsorption of Amyloid Beta-Peptide at Polymer Surfaces: A Neutron Reflectivity Study, Chem. Phys. Chem. 6 (2005), 25272534.

[22]E. P. Vieira, H. Hermel, and H. Mohwald, Change and Stabilization of the Amyloid-Beta(1-40) Secondary Structure by Fluorocompounds., Biochim. Biophys. Acta - Proteins and Proteomics 1645 (2003), 6-14.

[23]A. F. Thunemann, K. Sander, W. Jaeger, and R. Dimova, Polyampholyte-Dressed Micelles of Fluorinated and Hydrogenated Dodecanoic Acid, Langmuir 18 (2002), 5099-5105.

[24]S. Rocha, A. F. Thunemann, M. C. Pereira, M. A. N. Coelho, H. Mohwald, and G. Brezesinski, The Conformation of B18 Peptide in the Presence of Fluorinated and Alkylated Nanoparticles, Chem. Bio. Chem. 6 (2005), 280-283.

[25]W. Stober, A. Fink, and E. Bohn, Controlled Growth of Monodisperse Silica Spheres in Micron Size Range, J. Colloid Interface Sci. 26 (1968), 62-\&.

[26]N. Sreerama, and R. W. Woody, Estimation of Protein Secondary Structure from Circular Dichroism Spectra: Comparison of Contin, Selcon, and Cdsstr Methods with an Expanded Reference Set, Anal. Biochem. 287 (2000), 252-260.

[27]N. Sreerama, S. Y. Venyaminov, and R. W. Woody, Estimation of Protein Secondary Structure from Circular Dichroism Spectra: Inclusion of Denatured Proteins with Native Proteins in the Analysis, Anal. Biochem. 287 (2000), 243-251.

[28]J. Reed, and T. A. Reed, A Set of Constructed Type Spectra for the Practical Estimation of Peptide Secondary Structure from Circular Dichroism, Anal. Biochem. 254 (1997), 36-40.

[29]B. C. Poschner, J. Reed, D. Langosch, and M. W. Hofmann, An Automated Application for Deconvolution of Circular Dichroism Spectra of Small Peptides, Anal. Biochem. 363 (2007), 306-308.

[30]L. N. M. Duysens, The Flattening of the Absorption Spectrum of Suspensions, as Compared to That of Solutions, Biochim. Biophys. Acta 19 (1956), 1-12.

[31]D. M. Walsh, A. Lomakin, G. B. Benedek, M. M. Condron, and D. B. Teplow, Amyloid Beta-Protein Fibrillogenesis - Detection of a Protofibrillar Intermediate, J. Biol. Chem. 272 (1997), 22364-22372.

[32]M. D. Kirkitadze, M. M. Condron, and D. B. Teplow, Identification and Characterization of Key Kinetic Intermediates in Amyloid Beta-Protein Fibrillogenesis, J. Mol. Biol. 312 (2001), 1103-1119.

[33]D. A. Kirschner, C. Abraham, and D. J. Selkoe, X-Ray-Diffraction from Intraneuronal Paired Helical Filaments and Extraneuronal Amyloid Fibers in Alzheimer-Disease Indicates Cross-Beta Conformation, Proc. Natl. Acad. Sci. U. S. A. 83 (1986), 503-507.

[34]D. M. Walsh, I. Klyubin, J. V. Fadeeva, W. K. Cullen, R. Anwyl, M. S. Wolfe, M. J. Rowan, and D. J. Selkoe, Naturally Secreted Oligomers of Amyloid Beta Protein Potently Inhibit Hippocampal Long-Term Potentiation in Vivo, Nature 416 (2002), 535-539.

[35]C. J. Pike, A. J. Walencewicz, C. G. Glabe, and C. W. Cotman, Invitro Aging of Beta-Amyloid Protein Causes Peptide Aggregation and Neurotoxicity, Brain Res. 563 (1991), 311-314.

[36]L.D. Estrada, and C. Soto, Inhibition of Protein Misfolding and Aggregation by Small Rationally-Designed Peptides, Current Pharmaceutical Design 12 (2006), 2557-2567.

[37]M. Torok, M. Abid, S. C. Mhadgut, and B. Torok, Organofluorine Inhibitors of Amyloid Fibrillogenesis, Biochemistry 45 (2006), 5377-5383.

[38]R. Montserret, M. J. McLeish, A. Bockmann, C. Geourjon, and F. Penin, Involvement of Electrostatic Interactions in the Mechanism of Peptide Folding Induced by Sodium Dodecyl Sulfate Binding, Biochemistry 39 (2000), 8362-8373.

[39]K. A. Dill, and D. Shortle, Denatured States of Proteins, Annu. Rev. Biochem. 60 (1991), 795-825.

[40]H. J. Dyson, and P. E. Wright, Defining Solution Conformations of Small Linear Peptides, Annu. Rev. Biophys. Biophys. Chem. 20 (1991), 519-538.

[41]A. M. Gallardo-Moreno, C. M. Gonzalez-Garcia, M. L. Gonzalez-Martin, and J. M. Bruque, Arrangement of Sds Adsorbed Layer on Carbonaceous Particles by Zeta Potential Determinations, Colloids Surf. A: Physicochem. Eng. Aspects 249 (2004), 57-62.

[42]O. S. Makin, E. Atkins, P. Sikorski, J. Johansson, and L. C. Serpell, Molecular Basis for Amyloid Fibril Formation and Stability, Proc. Natl. Acad. Sci. U. S. A. 102 (2005), 315-320. 
[43]W. P. Esler, E. R. Stimson, J. R. Ghilardi, Y. A. Lu, A. M. Felix, H. V. Vinters, P. W. Mantyh, J. P. Lee, and J. E. Maggio, Point Substitution in the Central Hydrophobic Cluster of a Human Beta-Amyloid Congener Disrupts Peptide Folding and Abolishes Plaque Competence, Biochemistry 35 (1996), 13914-13921. 